\title{
Study on Mechanical Properties of Fiber Reinforced High Strength Light Weight
} Concrete

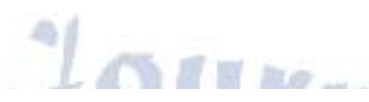

\author{
T.S.Vineel Kumar ${ }^{1} \mid$ A.Sai Kumar ${ }^{2} \mid$ Dr. Dumpa Venkateswarlu ${ }^{3}$ \\ ${ }^{1}$ PG Scholar, Department of Civil Engineering, Godavari Institute of Engineering \& Technology, Rajahmundry \\ ${ }^{2}$ Assistant Professor, Department of Civil Engineering, Godavari Institute of Engineering \& Technology, Rajahmundry \\ ${ }^{3}$ Professor \& Head, Department of Civil Engineering, Godavari Institute of Engineering \& Technology, Rajahmundry
}

To Cite this Article

T.S.Vineel Kumar, A.Sai Kumar and Dr. Dumpa Venkateswarlu, "Study on Mechanical Properties of Fiber Reinforced High Strength Light Weight Concrete", International Journal for Modern Trends in Science and Technology, Vol. 07, Issue 03, March 2021, pp.: 221-228.

Article Info

Received on 15-February-2021, Revised on 12-March-2021, Accepted on 17-March-2021, Published on 20-March-2021.

\section{ABSTRACT}

Concrete, one of the most universally accepted construction material, exhibits higher values of compressive strength, but the same cannot be said in terms of its tensile strength. This is the prime explanation for the setback of this construction material, to be used in place of achieving a higher tensile strength. Different endeavors have been made to improve the overall tensile strength of concrete by using diverse materials. These materials were used either as a form of replacement of its main constituents, or simply as an addition to the other constituents. Out of all such materials, the use of different types of fibers, added a definite proportion of tensile strength without actually altering the configuration of the concrete blocks to a larger extent. Also, in some cases the density of the concrete is a one of the influencing parameters in structural elements and this study is based on the optimization of fibers as a replacement of the Ordinary Portland cement (OPC) along with the use of different industrial waste by products i.e., mineral admixtures and also the light weight aggregates in order to reduce the self weight of the concrete. In this study, an attempt will be made to investigate the mechanical properties of $M 60$ grade high strength fiber reinforced light weight aggregate concrete.

KEYWORDS: High Strength Concrete, Fibers, Mineral admixtures, Mechanical Properties

\section{INTRODUCTION}

Ordinary Portland Cement is a major constituent material that is utilized in the manufacturing of concrete and it has no other alternative substitute in the field of civil engineering. The major problem with the cement production is it generates excessive amounts of green house gases (GHG's) into the atmosphere. Henceforth, it is recommended that cement should be replaced with other alternative and sustainable materials which shows no or less environmental influence.
Different types of studies are being conducted in and around the India in order to study the impact of industrial waste exhausts on the cement properties and the studies are resulted in a positive way. These industrial waste exhaust materials also termed as pozzolans, with their pozzolanic action. Various industrial waste materials like GGBS, silica ash, rice husk etc are abundantly available in different parts of India and are being extensively used as replacements to the cement. 
The major problem with the plain concrete is its low tensile capacity, limitations in the aspect of ductility and lower resistance to the cracking and the low tensile strength is because of the propagation and extension of the aspect of micro cracking.

Generally, in PCC (plain cement concrete) micro cracks initiates before the time of loading because of the two critical aspects like drying shrinkage or due to the change in volume. The dimensions of such cracks ranges from microns to $\mathrm{mm}$. When the concrete elements are loaded, such micro cracks gets open up and some additional cracks also forms in the places where there is strength deficiency due to various sequences. The propagation of such micro cracking is the phenomenal cause of the in elastic deformations in the concrete structures. The inculcation of micro uniformly dispersed fibers to the concrete behaves as crack arrester and they improve the dynamic as well as static properties of concrete and such concrete is termed to be fiber reinforced concrete (F.R.C)

\subsection{NECESSITY}

Because of the good durability and strength characteristic properties, cement concrete is the generally utilized construction material all over the world. Despite of the fact that the generation of cement produces huge amounts of green house gases into atmosphere, it is being utilized. Keeping this aspect in view, the utilization of pozzolanic materials into the concrete as replacement to cement is found to be an effective alternative for this problem.

The industrial waste exhaust material from the steel industry is GGBS which is termed as ground granulated blast furnace slag and is obtained by the quenching of the molten iron slag under the blast furnace within a steam bath or water bath. It has high durable properties and it can be used to prepare good concrete. It is being extensively utilized in various areas of the world, due to its superior durable properties.

Further, the self weight of the concrete material also shows a significant impact on the load bearing capacity of the high rise buildings and it is concluded that the designers of such buildings are unable to transfer the loads efficiently because of their own weight. Keeping this aspect in view, light weight concrete has gained a lot of interest by the researchers so as to answer the structural as well as architectural aspects.

\subsection{Light Weight Aggregate Concrete}

The light weight aggregate concrete which is used for structural purposes has the unit weight (density) in the range of $1450-1850 \mathrm{~kg} / \mathrm{m}^{3}$ when compared with natural weight aggregate concrete which has a density in the range of 2400-2500 $\mathrm{kg} / \mathrm{m}^{3}$. Generally, for the purpose of application of concrete in structures, the strength of concrete should be greater than that of $17 \mathrm{MPa}$. The concrete mix which is prepared by using light weight aggregate has equivalent strength on par with the specifications. In most of the cases, the fine aggregate is termed to be a light weight product. They are utilized in light weight concrete (L.W.C). The light weight aggregates like expanded clay, slate, shale, blast slag, hematite are utilized for various structural applications with low extent of density when compared with regular concreting materials and they have very good insulation properties.

\subsection{SCOPE}

The investigation was performed on High Strength Grade ie., M60 grade concrete by using glass fibers and GGBS as mineral admixture The OPC was replaced by GGBS in the proportions of $0,10 \%, 20 \%, 30 \%, 40 \%$ and glass fibers in the range of $0.5 \%, 1 \%, 1.5 \%, 2 \%$ with a SP dosage of $1.5 \%$ by weight of cement for mix along with $10 \%, 20 \%, 30 \%$ and $40 \%$ pumice stone as replacement to coarse aggregate.Mixes were prepared, cured and tested for identifying the mechanical strength characteristics of concrete after 28 days of conventional curing.

\subsection{Objectives of the Study}

a. To design fiber reinforced high strength light weight concrete by using optimized content of glass fibers and multi-mineral admixtures as well as the light weight aggregates.

b. To study the mechanical strength characteristics of HSC [M60] fiber reinforced high strength concrete and also the weight reduction of the concrete.

\section{RELATED WORK}

Harish B A et al., (2016) [1] investigated on the M20 grade steel fiber concrete. They have investigated the influence of crimped steel fibers of aspect ratio 60 on the mechanical strength for M20 grade of concrete. Few Regression Models were deduced to estimate the strengths for CSFRC with respect to curing period and percentage of fiber. Conclusions are made by comparing the experimental and analytical results.

A.K.Jain (2016) [2] examined the impact of steel \& glass fibres on the mechanical strength 
characteristics of the concrete. The investigation included different mechanical strength tests to concrete. 2 types of fibres were used and they are steel and glass. The goal of this study is to identify the mechanical strength characteristics of hybrid fibre concrete of M20 grade with various proportions and volume fractions of fibres ranging from $0.2-0.35 \%$. The test results reported that the mixes with hybrid fibres reported enhanced mechanical properties than control concrete.

Pravin Gorse (2015) [3] have studied the impact of GGBS addition on mechanical strength characteristics of F.R.C. In this investigation, M50 grade concrete was chosen and GGBS is used to replace cement in proportions of $10-40 \%$ by weight of cement in the intervals of $10 \%$. The percentage of steel fibres is taken as $1.5 \%$ and kept constant. The variables in this study were aggregate size as well as GGBS percentage in order to study the impact of aggregate size and GGBS percentage variation on the fresh and hardened properties. Standard specimens sizes were used and the specimens with GGBS were wet cured for 56 days and normal concrete cubes were cured for 28 days. All the specimens were tested for mechanical strength characteristics. The test results reported that with the addition of GGBS and fibres, the mechanical strength characteristics were enhanced .

Siddharth et al (2015) [4] conducted a study on the partial cement replacement by utilizing the industrial waste exhausts like GGBS. In their study, the mechanical strength characteristics of the concrete were studied by replacing GGBS in the proportions of $10-40 \%$ by weight of cement and $1 \%$ steel fibers of round crimped type were utilized. From the study, it is concluded that the optimal replacement of GGBS to cement is $40 \%$ and also the load bearing capacity of the beams is maximum at $40 \%$ replacement of cement with GGBS.

S.N.Ahamed Ibrahim (2012) [5] explored about the strength characteristics of steel fiber concrete by using steel fibers of different ranges from $0.5-1.5 \%$, with an interval of $0.5 \%$ and various mechanical strength characteristic related elements were casted, cured and tested. The test results reported that the optimal percentage of steel fibers in concrete is $1.5 \%$.

S. S. Vidhale (2013) [6]investigated about the design mix of F.R.C utilizing steel fibers and GGBS. The study was aimed on the mechanical strength performance of concrete having various percentages of the above mentioned materials to OPC. It is replaced with GGBS with the percentages of $10-40 \%$ and steel fibre in the range of $0.5-2 \%$.
The mechanical strength characteristic specimens were casted, cured and tested for a period of 3,7 \& 28 days of curing. The prepared mix strength performance is compared with controlled concrete. From this study, it was concluded that the optimal replacement of GGBS to OPC is $20 \%$ and optimal percentage of steel fibre is $1.5 \%$ respectively for M20-M40 grade concrete.

Ajay N. Burile et al., (2013) [7]performed a study on S.F.R.C and G.F.R.C composites. Steel fibres with hooked end with a aspect ratio of 50 and alkaline resistive glass fibres with percentages of 0-0.25 by weight of cement. On par with the control concrete, the F.R.C mechanical characteristics were found to be superior and $0.25 \%$ addition of fibres were reported to be optimal content for both the cases.

J. Venkateswara Rao et al., (2014) [8] studied on behaviour of F.R.C for rigid pavement applications. The investigation included M20 concrete with polyester fibres in the volume fractions of $0.1 \%, 0.2 \%, 0.3 \%$ and $0.4 \%$ by cement weight. A comparison analysis was performed between controlled and F.R.C concrete in terms of their mechanical strength characteristics. The test results reported that with the increase in fibre content, the strength of mixes also increases. It is concluded that $0.3 \%$ of fibres is reported to be optimal content.

Mohd Khawaja Hussain et al (2015) [9] conducted a study on the strength characteristics of hybrid fiber concrete in which steel and coconut fibers are utilized. M20 concrete was chosen with $\mathrm{w} / \mathrm{c}$ ratio of 0.45 with proportion mix of 1.1.53:2.69 so as to identify the mechanical strength characteristics. Further, industry waste like fly ash by weight of cement in range of $10-30 \%$ with an interval of $10 \%$ was utilized. Steel and polypropylene fibers with a length of $50 \mathrm{~mm}$ in the percentages of $1-3 \%$ with an interval of $1 \%$ were done. Strength tests were performed after 28 days of conventional curing and the optimal dosage of fly ash and steel fibers are reported to be $20 \%$ and $2 \%$ and the optimal dosage of fly ash and coconut fibers are reported to be 20 and $1 \%$. Steel fibers showed enhanced strength characteristics than coconut fibers.

S.Prakash Chandar et al., (2015) [10] performed a study on strength characteristics of steel and jute fibre concrete. The investigation reported that the physical characteristics of the utilized fibres in the study have reported no deterioration in the concrete medium and can be 
used for structural applications abundantly and they are also eco-friendly.

A.K.Jain (2016) [11] examined the impact of steel and glass fibres on strength properties of concrete and this study is continued by studying the strength characteristics of H.F.R.C. 2 fibers namely steel and glass fibres were utilized in the study and the objective of this study is to investigate the strength characteristics of M20 concrete with ranges of $0.2-0.35 \%$ of glass and $0.4-0.55 \%$ of steel fibres by volume of concrete. From the test results, it is reported that the mixes containing hybrid fibres shown superior properties than controlled concrete.

Pajak et al. (2012) [12] investigated the flexural characteristic of S.C.C. reinforced with steel fibers in the range of $0.5-1.5 \%$ with an interval of $0.5 \%$ and is compared with normal vibrated concrete NVC. The testing of specimens is done on par with the compliance requirements of RILEM TC 162-TDF. The flexural characteristic of $\mathrm{SCC}$ is relatable to NVC, in which the fiber volume ratio increase causes the increase in pre and post crack parameters of SCC. With the utilization of fibers, the flexural strength of concrete increased substantially.

\section{III.EXPERIMENTAL STUDY MATERIALS AND METHODS}

\subsection{Design of Proposed Mix}

The design of proposed concrete mix was done for M 60 on par with the specifications of ACI:211-4R code with normal constituent materials like Ultra Tech OPC 53 grade cement, river sand \& mechanically crushed $20 \mathrm{~mm}, 12 \mathrm{~mm} \& 6 \mathrm{~mm}$ conventional granite were using along with Pumice stone as replacements to coarse aggregate and glass fibers were used.The study was carried out in 2 phases. In phase-I, natural granite aggregate is replaced with pumice stone in percentages of $10 \%, 20 \%, 30 \% \quad \& \quad 40 \%$ along with GGBS replacement levels to cement in the percentages of 0,10\%, 20\%, 30\% and 40\% .After obtaining optimal values from the above phase, a strategy has been developed to enhance the compressive strength by incorporating the glass fibers to enhance the performance behavior of high strength grade light weight concrete.

\subsection{Mix Proportioning}

In the present study, M60 grade concrete with the mix proportions of 1:1.11:2.09 with $\mathrm{w} / \mathrm{c}$ ratio of 0.3 was adopted and is the process of mix design that is carried out as per the specifications of ACI:211.4R-93 methodology.

\section{TEST RESULTS AND DISCUSSION}

Table 1: Test Results of Mechanical Properties of High Strength Concrete with the replacement of mineral admixtures at 28 day

\begin{tabular}{|c|c|c|c|c|c|c|}
\hline $\begin{array}{c}\text { S.N } \\
0\end{array}$ & $\begin{array}{c}\text { Mix } \\
\text { Designat } \\
\text { ion }\end{array}$ & $\begin{array}{c}\text { Mix } \\
\text { Proportio } \\
n\end{array}$ & $\begin{array}{c}\% \text { of } \\
\text { Minera } \\
1 \\
\text { Admixt } \\
\text { ures }\end{array}$ & $\begin{array}{c}\text { Compre } \\
\text { ssive } \\
\text { Strengt } \\
\mathrm{h} \\
(\mathrm{Mpa})\end{array}$ & $\begin{array}{l}\text { Tensil } \\
\text { e } \\
\text { Stren } \\
\text { gth } \\
\text { (Mpa) }\end{array}$ & $\begin{array}{l}\text { Flexu } \\
\text { ral } \\
\text { Stren } \\
\text { gth } \\
\text { (Mpa) }\end{array}$ \\
\hline 1. & $\begin{array}{c}\text { M60[M1] } \\
\text { Control } \\
\text { Mix }\end{array}$ & $\begin{array}{c}1: 1.11: 2 \\
09 \\
\mathrm{~W} / \mathrm{C}= \\
0.3\end{array}$ & 0 & 60.67 & 4.14 & 7.95 \\
\hline 2. & $\begin{array}{c}\text { M60 } \\
\text { [M2] } \\
10 \% \\
\text { GGBS } \\
1.5 \% \text { SP }\end{array}$ & $\begin{array}{c}1: 1.08: 2 \\
09 \\
W / B= \\
0.3\end{array}$ & 10 & 67.11 & 4.38 & 8.75 \\
\hline 3. & $\begin{array}{c}\text { M60 } \\
\text { [M3] } \\
20 \% \\
\text { GGBS } \\
1.5 \% \text { SP }\end{array}$ & $\begin{array}{c}1: 1.08: 2 \\
09 \\
W / B= \\
0.3\end{array}$ & 20 & 64.44 & 3.68 & 5.40 \\
\hline 4. & $\begin{array}{c}\text { M60 } \\
{[\mathrm{M} 4]} \\
30 \% \\
\text { GGBS } \\
1.5 \% \text { SP }\end{array}$ & $\begin{array}{c}1: 1.07: 2 . \\
09 \\
\mathrm{~W} / \mathrm{B}= \\
0.3\end{array}$ & 30 & 61.54 & 2.83 & 5.8 \\
\hline 5. & $\begin{array}{c}\text { M60 } \\
\text { [M5] } \\
40 \% \\
\text { GGBS } \\
1.5 \% \text { SP }\end{array}$ & $\begin{array}{c}1: 1.07: 2 . \\
09 \\
\mathrm{~W} / \mathrm{B}= \\
0.3\end{array}$ & 40 & 57.78 & $\begin{array}{l}3.53 \\
y \\
y\end{array}$ & 7.87 \\
\hline
\end{tabular}

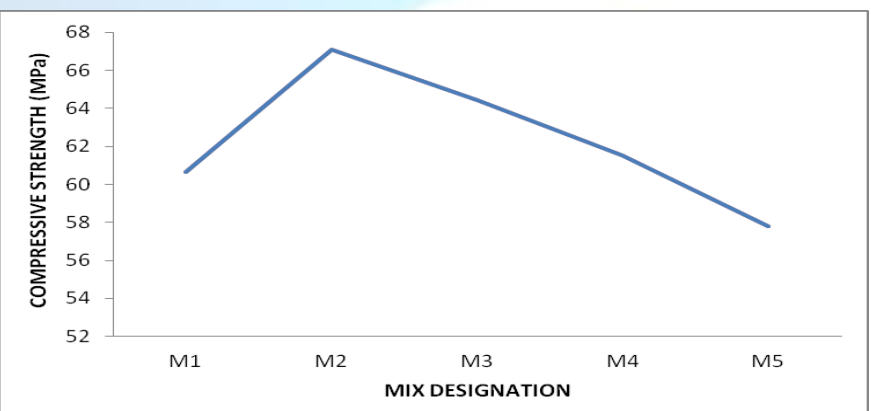

Fig.1Compressive strength results of High Strength Concrete with the replacement of mineral admixtures at 28 days 


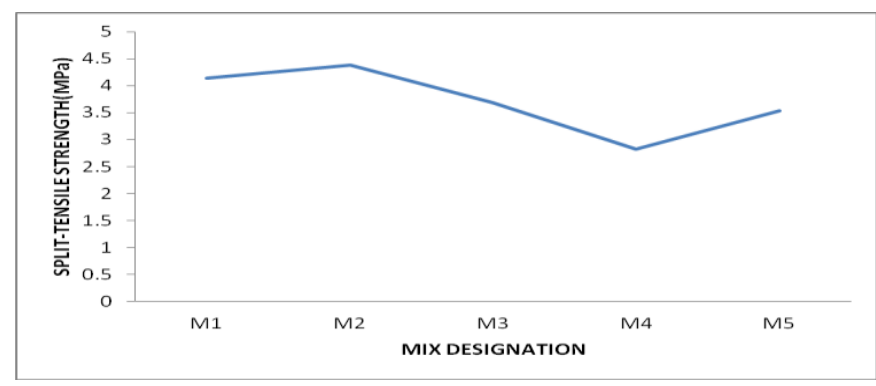

Fig.2 Split-tensile strength of High Strength Concrete with the replacement of mineral

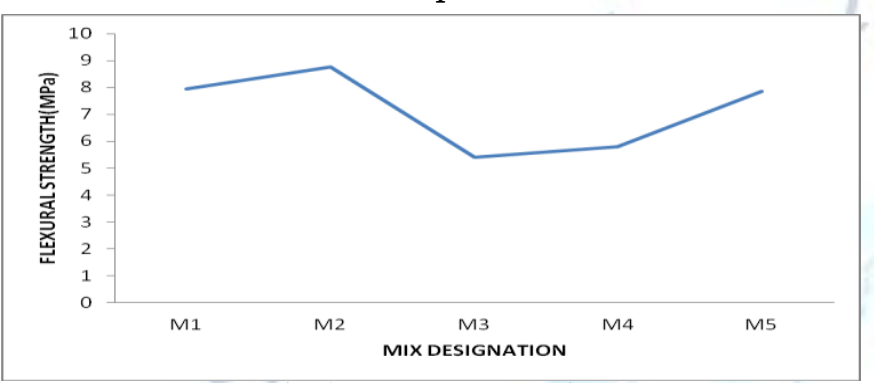

admixtures at 28 days

Fig.3 Flexural Strength of High Strength Concrete with the replacement of mineral admixtures at 28 days

From Fig. 1,2 \& 3, it can be concluded that the optimal replacement level of GGBS to achieve high strength grade concrete is $10 \%$ since, the mix has yielded better mechancial properties than the other mixes. Hence for the further study, Mix M2 is taken as reference mix for the second phase of study.

Table.2 Test Results of Mechanical Properties of High Strength Concrete with the replacement of mineral admixtures $\&$ pumice stone at 28 days

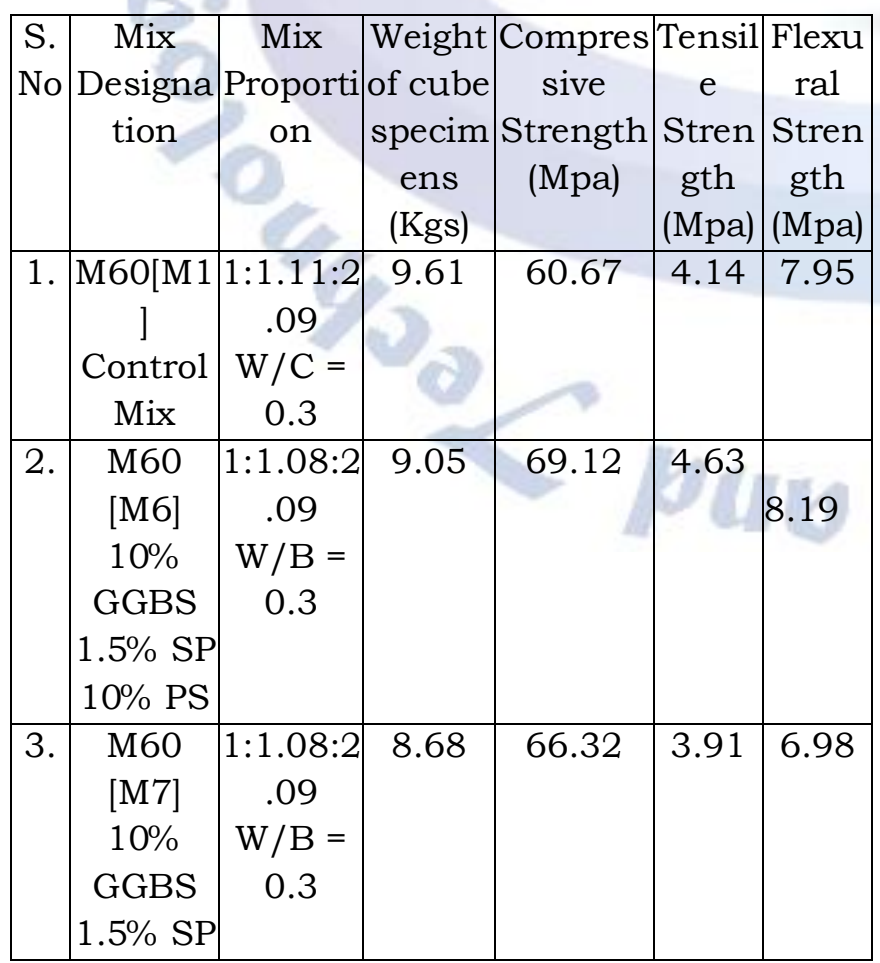

\begin{tabular}{|c|c|c|c|c|c|c|}
\hline & $20 \% \mathrm{PS}$ & & & & & \\
\hline 4. & \begin{tabular}{|c|} 
M60 \\
{$[\mathrm{M} 8]$} \\
$10 \%$ \\
GGBS \\
$1.5 \% \mathrm{SP}$ \\
$30 \% \mathrm{PS}$
\end{tabular} & \begin{tabular}{|c}
$1: 1.07: 2$ \\
.09 \\
$\mathrm{~W} / \mathrm{B}=$ \\
0.3
\end{tabular} & 8.30 & 63.10 & 3.10 & 5.94 \\
\hline 5. & \begin{tabular}{|c|} 
M60 \\
[M9] \\
$10 \%$ \\
GGBS \\
$1.5 \%$ SP \\
$40 \%$ PS
\end{tabular} & $\begin{array}{c}1: 1.07: 2 \\
.09 \\
\mathrm{~W} / \mathrm{B}= \\
0.3\end{array}$ & 8.00 & 58.23 & 2.89 & 4.98 \\
\hline
\end{tabular}

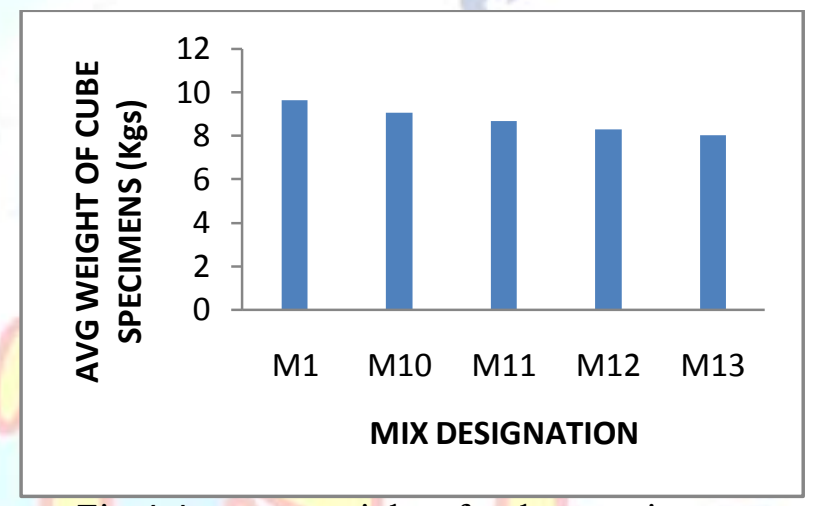

Fig.4 Average weight of cube specimens

From Fig.4, it can be concluded that with the increase in percentage repalcement of pumice stone aggregate to natural coarse aggregate, the weight of the cube specimens is decreasing and also the compressive strength of high strength grade light weight concrete is found to be increasing and for Mix M8 the percentage decrease in weight of the cube specimen is $13.63 \%$.

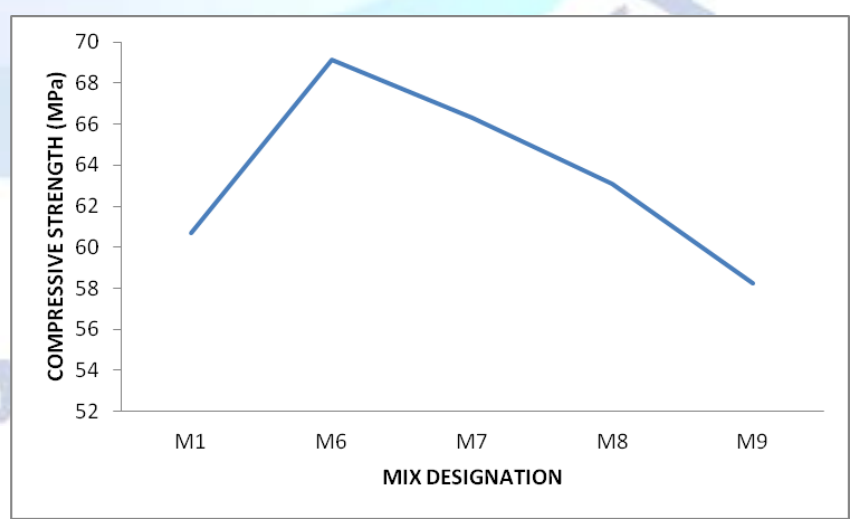

Fig. 5 Compressive strength results of High

Strength Concrete with the replacement of mineral admixtures and pumice stone at 28 days 


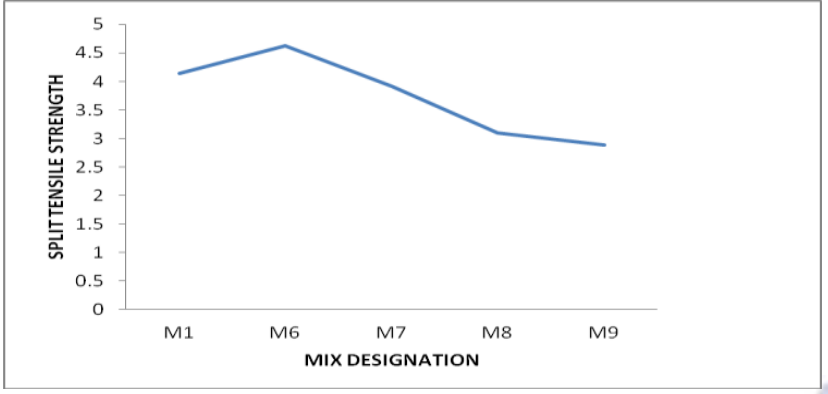

Fig.6 Split-tensile strength of High Strength Concrete with the replacement of mineral admixtures $\&$ pumice stone at 28 days

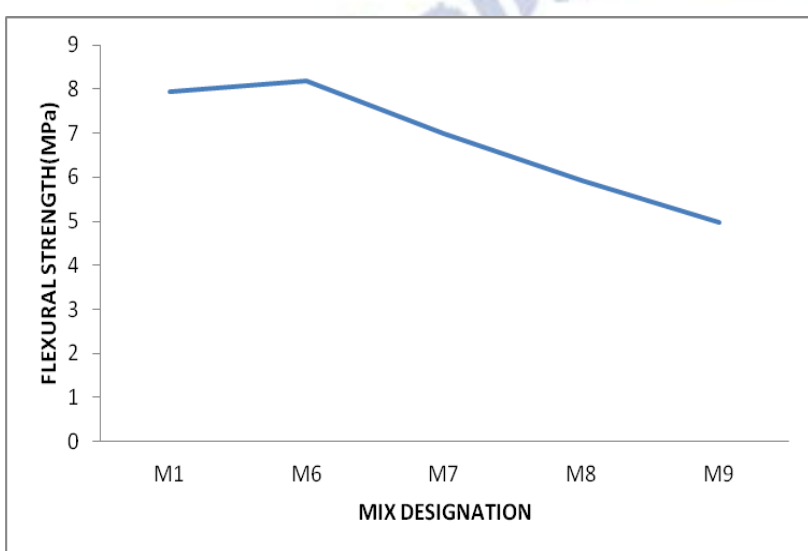

Fig.7 Flexural Strength of High Strength Concrete with the replacement of mineral admixtures and pumice stone at 28 days

Forthe third phase of study, the mix designation M6 is taken as reference mix and the study is continued by using glass fibers in the volume fraction of $0.5 \%, 1 \%, 1.5 \%$ and $2 \%$ replacement levels to the cement.
Table.3 Test Results of Mechanical Properties of High Strength light weight Concrete with the replacement of mineral admixtures $\&$ pumice stone at 28 days

\begin{tabular}{|c|c|c|c|c|c|c|c|}
\hline \begin{tabular}{|l|} 
S. \\
No
\end{tabular} & $\begin{array}{c}\text { Mix } \\
\text { Design } \\
\text { ation }\end{array}$ & \begin{tabular}{|c|} 
Mix \\
Proport \\
ion
\end{tabular} & \begin{tabular}{|c} 
Weight \\
of \\
cube \\
specim \\
ens \\
(Kgs)
\end{tabular} & \begin{tabular}{c|c}
$\%$ & \\
of & \\
gla & \\
ss \\
fibe \\
rs
\end{tabular} & $\begin{array}{c}\text { Compre } \\
\text { ssive } \\
\text { Strengt } \\
\mathrm{h} \\
\text { (Mpa) }\end{array}$ & $\begin{array}{l}\text { Tensi } \\
\text { le } \\
\text { Stren } \\
\text { gth } \\
\text { (Mpa) }\end{array}$ & \begin{tabular}{|} 
Flexu \\
ral \\
Stren \\
gth \\
$(\mathrm{Mpa})$
\end{tabular} \\
\hline 1. & $\begin{array}{c}\text { M60[M } \\
1] \\
\text { Control } \\
\text { Mix }\end{array}$ & $\begin{array}{c}1: 1.11: \\
2.09 \\
\mathrm{~W} / \mathrm{C}= \\
0.3\end{array}$ & 9.61 & 0 & 60.67 & 4.14 & \begin{tabular}{|l|}
7.95 \\
\end{tabular} \\
\hline 2. & \begin{tabular}{|c|} 
M60 \\
[M10] \\
$10 \%$ \\
GGBS \\
$1.5 \%$ \\
SP \\
$10 \%$ PS \\
$0.5 \%$ \\
GF
\end{tabular} & $\begin{array}{c}1: 1.08: \\
2.09 \\
W / B= \\
0.3\end{array}$ & 9.12 & 0.5 & 68.98 & 8 & 8.12 \\
\hline 3. & \begin{tabular}{|c|} 
M60 \\
[M11] \\
$10 \%$ \\
GGBS \\
$1.5 \%$ \\
SP \\
$20 \%$ PS \\
$1 \%$ GF \\
\end{tabular} & $\begin{array}{c}1: 1.08: \\
2.09 \\
W / B= \\
0.3\end{array}$ & 8.78 & 1 & 69.21 & 4.82 & 8.35 \\
\hline 4. & \begin{tabular}{|c|} 
M60 \\
[M12] \\
$10 \%$ \\
GGBS \\
$1.5 \%$ \\
SP \\
$30 \%$ PS \\
$1.5 \%$ \\
GF
\end{tabular} & $\begin{array}{c}1: 1.07: \\
2.09 \\
W / B= \\
0.3\end{array}$ & 8.40 & 1.5 & 70.28 & 5.1 & 8.64 \\
\hline 5. & \begin{tabular}{|c|} 
M60 \\
[M13] \\
$10 \%$ \\
GGBS \\
$1.5 \%$ \\
SP \\
$40 \%$ PS \\
$2 \%$ GF
\end{tabular} & $\begin{array}{c}1: 1.07: \\
2.09 \\
\mathrm{~W} / \mathrm{B}= \\
0.3\end{array}$ & $\begin{array}{c}8.14 \\
9\end{array}$ & 2 & 68.15 & 4.81 & 7.69 \\
\hline
\end{tabular}




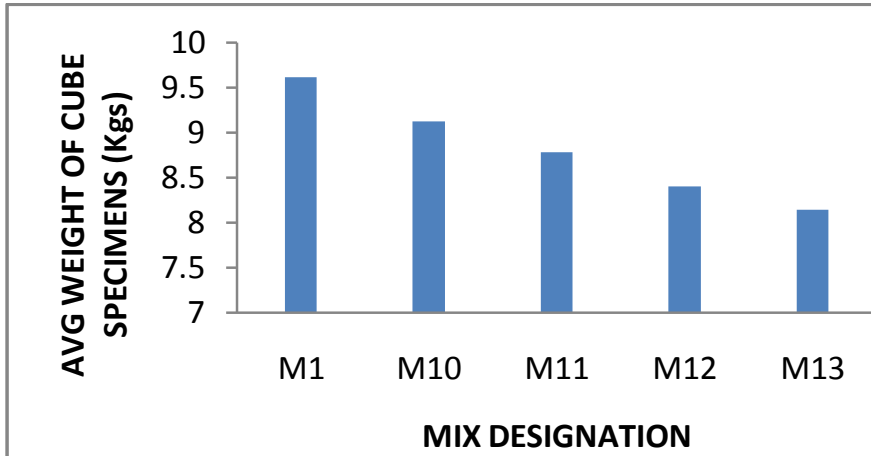

Fig.8 Average Weight of cube specimens

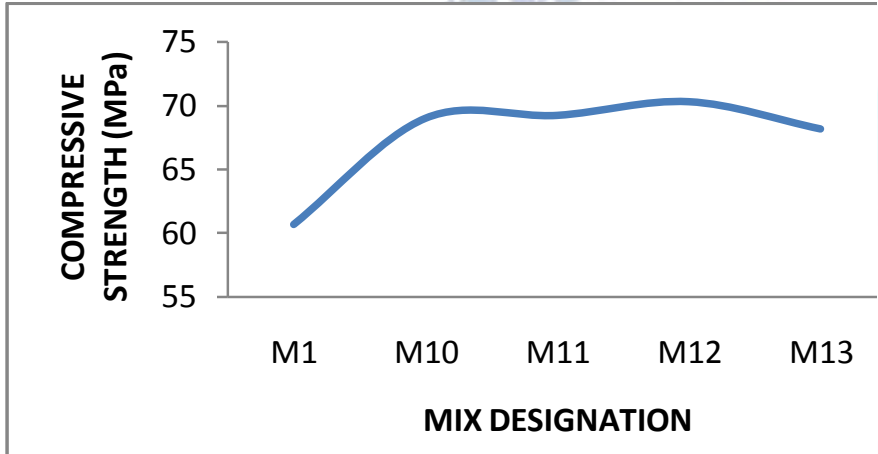

Fig.9 Compressive strength results of High Strength Concrete with the replacement of mineral admixtures,pumice stone and glass fibers at 28 days

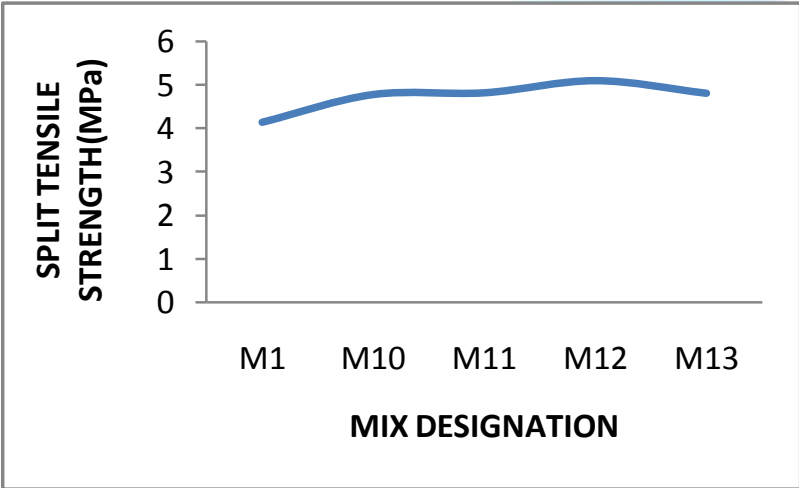

Fig.10 Split-tensile strength of High Strength

Concrete with the replacement of mineral admixtures $\&$ pumice stone and glass fibers at 28 days

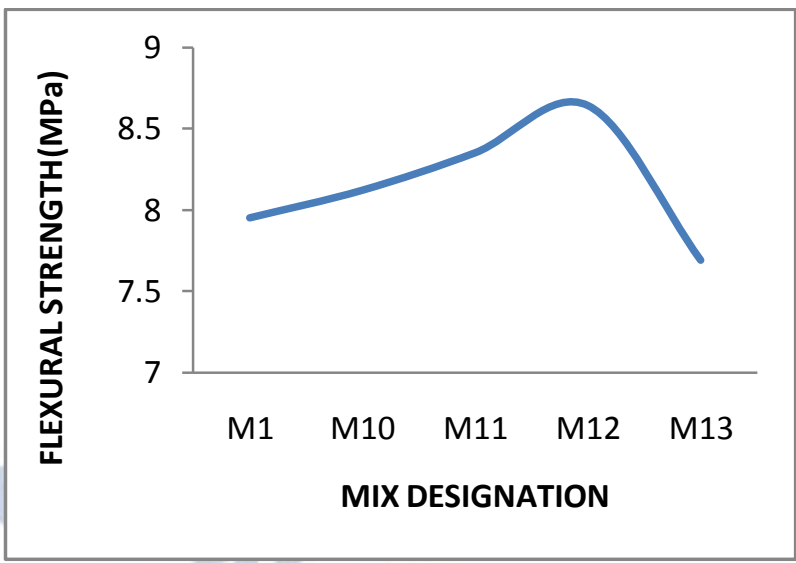

Fig.11 Flexural Strength of High Strength Concrete with the replacement of mineral admixtures and pumice stone $\&$ glass fibers at 28 days

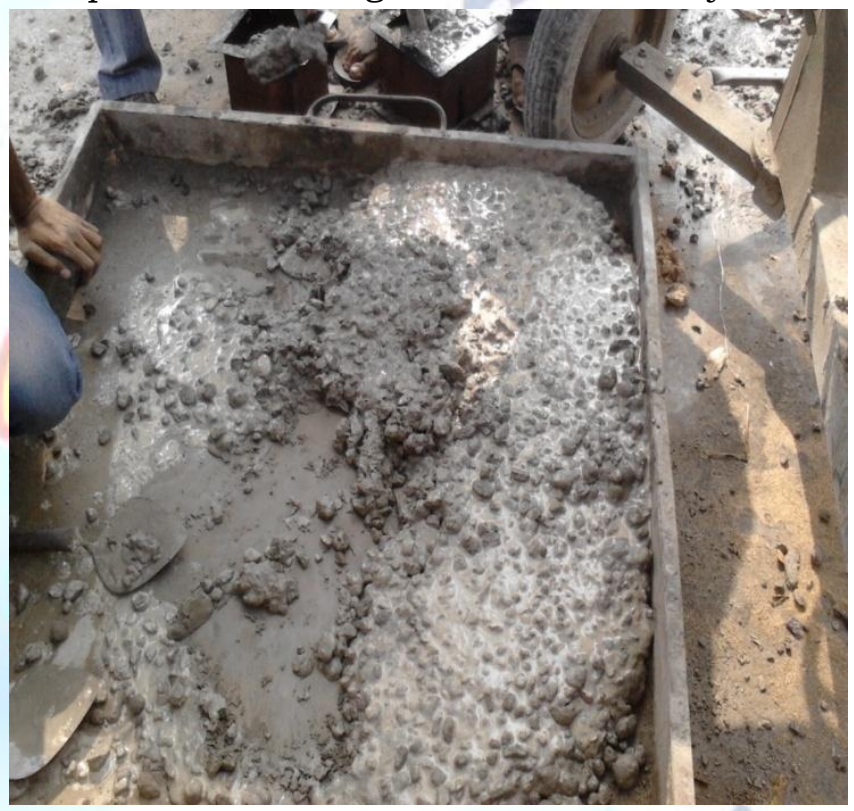

Fig.12 Fresh Concrete Mix

\section{CONCLUSIONS}

1. By using $30 \%$ of light weight aggregate as a partial replacement to natural coarse aggregate with mineral admixtures and glass fibers the compressive strength attained the target mean strength.

2. The density of concrete is found to decrease with the increase in percentage replacement of natural aggregate by pumice aggregate.

3. The compressive strength of concrete is found to decrease with the increase in pumice content from $8.1 \%$ to $29.30 \%$

4. With the addition of mineral admixtures and glass fibers, the compressive, split-tensile and flexural strengths of concrete are increased.

5. Light weight aggregate is no way inferior to natural coarse aggregate and it can be used for construction purpose. 


\section{REFERENCES}

[1] Harish B A et al "Experimental Study on the M20 Grade Cement Concrete Containing Crimped Steel Fibres", International Journal of Science Technology \& Engineering, Volume 3, Issue 03, September 2016.

[2] S.N.Ahamed Ibrahim, "Study Of Mechanical Properties Of Steel Fiber Concrete", International Journal of Computer \& Organization Trends - Volume 2 Issue 6 Number 1 - Nov 2012.

[3] S. S. Vidhale, "Mix Design of Fiber Reinforced Concrete (FRC) Using Slag \& Steel Fiber", International Journal of Modern Engineering Research (IJMER) www.ijmer.com Vol. 3, Issue. 6, Nov - Dec. 2013 pp-3863-3871.

[4] Ajay N. Burile, "Comparative Study of Steel and Glass Fiber Reinforced Concrete Composites", International Journal of Science and Research,

[5] J. Venkateswara Rao, "Experimental study on behavior of fiber reinforced concrete for rigid pavements" , IOSR Journal of Mechanical and Civil Engineering, e-ISSN: 2278-1684,p-ISSN: 2320-334X, Volume 11, Issue 4 Ver. VII (Jul- Aug. 2014), PP 49-53

[6] Mohd Khawaja Hussain, "A Study On Strength Of Concrete By Partial Replacement Of Cement With Fly Ash In Addition With Steel Fiber And Coconut Fiber", International Journal Of Engineering Sciences \& Research Technology, [Hussain*, 4.(6): June, 2015] ISSN: 2277-96.

[7] S.Prakash Chandar, "Experimental Study On The Mechanical Properties Of Concrete Mixed With Jute Fiber And Steel Fiber",International Research Journal of Engineering and Technology (IRJET) e-ISSN: 2395 -0056 Volume: 02 Issue: 02 | May-2015.

[8] Pravin Gorse ,"Experimental study on behavior of fiber reinforced concrete for rigid pavements", IOSR Journal of Mechanical and Civil Engineering (IOSR-JMCE) e-ISSN: 2278-1684,p-ISSN: 2320-334X, Volume 11, Issue 4 Ver. VII (Jul- Aug. 2014), PP 49-53

[9] Siddharth, Seetharam.Munnur "Experimental Study on Strength Properties of Concrete using Steel Fibre and GGBS as Partial Replacement of Cement", International Journal of Engineering Research \& Technology, Vol. 4 Issue 01,January-2015.

[10] P.Muthupriya, K.Subramanian, B.G.Vishnuram, "Experimental Investigation on High Performance Reinforced Concrete Column with Silica Fume and Fly Ash as admixtures". Asian Journal of Civil Engineering, Vol.12, No. 5 (2011), Pages 597-618.

[11] B.B.Patil, P.D. Kumbhar "Strength and Durability Properties of high Performance Concrete incorporating High Reactivity Metakaolin", International Journal of Modern Engineering Research, Vol.2, issue.3,May-June 2012,pages 1099-1104.

[12] A.Ravichandran, K.Suguna and P.N.Raghunath "Strength Modeling of High-strength concrete with Hybrid Fiber Reinforcement". American Journal of Applied Sciences 6 (2):219-233, 2009.

[13] S. Eswari, P.N. Raghunath and K. Suguna,"Ductility Performance of Hybrid Fibre Reinforced Concrete", American Journal of Applied Sciences 5 (9): 1257-1262, 2008, ISSN 1546-9239, 2008 Science Publications

[14] Dr.Salahldein Alsadey "Influence of Superplasticizer on Strength of Concrete”, International Journal of Research in Engineering and Technology, Vol.1, No.3, 2012

[15] N. Sivalinga Rao, Y.Radha Ratna Kumari, V. Bhaskar Desai, B.L.P. Swami, "Fibre Reinforced Light Weight Aggregate (Natural Pumice Stone) Concrete", International
Journal of Scientific \& Engineering Research Volume 4, Issue 5, May-2013 ISSN 2229-5518.

[16] S.Chandra and Berntsson, Light weight aggregate concrete: Science, technology and applications, Noyes Publications.

[17] Swamy R.N, Lambert G.H, "Mix Design and Properties of Concrete made from PFA, Coarse Aggregate and Sand", The International Journal of Cement Composite and Light Weight Concrete, Vol.5, No.4, 1983, PP 263-275.

[18] Taylor.P.C, "The Properties of High Strength Light Weight Concrete", Concrete 21(4), April 1987, pp 8-9.

[19] T. Parhizkar, M. Najimi and A.R. Pourkhorshidi, "Application of pumice aggregate in structural lightweight concrete", asian journal of civil engineering (building and housing) VOL. 13, NO. 1 (2012) PAGES 43-54.

[20] ACI Committee 318, Building Code Requirements for Reinforced Concrete (ACI 318-05) and Commentary, American Concrete Institute, Detroit, Mich, USA, 2005.

[21] Building Research Establishment, "Autoclaved aerated concrete," Building Research Establishment Digest 342, pp. 1-8, March 1989.

[22] A. S. Ezeldin and P. N. Balaguru, "Normal- and high-strength fiber-reinforced concrete under compression," Journal of Materials in Civil Engineering, vol. 4, no. 4, pp. 415-429, 1992.

[23] C. H. Henager, "Steel fibrous concrete-a review of testing procedures," in Proceedings of the Symposium on Fiber Concrete, pp. 16-28, London, UK, 1980.

[24] C. D. Johnston, Fiber Reinforced Cements and Concretes, Gordon and Breach Science, Amsterdam, The Netherlands, 2001.

[25] R. N. Swamy, P. S. Mangat, and C. V. S. K. Rao, The Mechanics of Fiber Reinforcement of Cement Matrices, Fiber Reinforced Concrete, SP 44, American Concrete Institute, Detroit, Mich, USA, 1973. 